\title{
Perancangan Sistem Informasi Data Kependudukan Pada Cluster PT. Alam Sutera Realty Tbk.
}

\author{
Yulita \\ Program Studi Sistem Informasi \\ STMIK Dharma Putra \\ yulita_limarx@yahoo.com
}

\author{
Yakub \\ Fakultas Sains dan Teknologi \\ Universitas Buddhi Dharma \\ y44kub@yahoo.com
}

\author{
Wiyoso \\ Fakultas Sains dan Teknologi \\ Universitas Buddhi Dharma \\ wiyono.hermanto@yahoo.com
}

\begin{abstract}
Abstrak- PT. Alam Sutera Realty Tbk bergerak di bidang pemasaran hunian real estate yang menerapkan cluster system di kawasan perumahan. Hal ini menjadikan pendataan dari mulai penghuni, tamu yang berkunjung sampai pembayaran iuran keamanan penghuni dari tiap cluster sangat penting. Oleh karena itu, dirancang sistem informasi data kependudukan pada cluster PT. Alam Sutera Realty Tbk. Hasil dari penelitian yang dilakukan diharapkan dapat mempermudah divisi estate dalam mendata lokasi semua penduduk yang tersebar di beberapa cluster berikut laporan iuran dan dapat mempermudah petugas keamanan di setiap cluster untuk mendata tamu yang berkunjung, serta mempermudah memberikan informasi kepada tamu. Rancangan yang dibuat menjadi fasilitas yang sangat berguna bagi perusahaan dalam menjalankan usahanya dan menetapkan kebijakan.
\end{abstract}

Kata Kunci- Cluster, Perancangan, Sistem Informasi, Database

\section{Pendahuluan}

Seiring dengan perkembangan teknologi informasi yang berkembang pesat saat ini, banyak bidang yang terus berpacu mengikuti perkembangan teknologi informasi. Teknologi informasi mempunyai peranan yang penting di dalam suatu usaha menciptakan persaingan bisnis. Penerapan teknologi informasi dirasa perlu bagi sebuah pengembangan kawasan hunian untuk memberikan kemudahan dalam penyampaian informasi.

PT. Alam Sutera Realty Tbk bergerak di bidang pemasaran hunian real estate yang menerapkan cluster system di kawasan perumahan. Saat ini telah dikembangkan lebih dari 20 cluster yang masing-masing terdiri dari 150 sampai 300 hunian dan dihuni oleh sedikitnya 2.500 keluarga.

Cluster system merupakan sistem perumahan yang tidak menggunakan pagar. Hal ini menjadikan pendataan dari mulai penghuni, tamu yang berkunjung, sampai pembayaran iuran keamanan penghuni dari tiap-tiap cluster sangat penting.

Permasalahan yang ada di PT. Alam Sutera Realty Tbk adalah pada proses data kependudukan yang berada di Adm Estate. Pendataan data pemilik dan penghuni berikut iuran bulanan yang kurang akurat, pendataan tamu yang berkunjung hanya sebatas lisan tanpa pengecekkan lebih lanjut, penduduk yang meninggalkan rumahnya tidak terekam menjadikan Adm
Estate mengalami kesulitan untuk membuat laporan yang diinginkan oleh pihak pengelola dan penduduk.

Pendataan penduduk dan iuran bulanannya tidak menghasilkan laporan yang akurat. Terlebih pendataan tamu yang berkunjung hanya dilakukan sebatas lisan dan pencatatan nomor polisi di sebuah buku. Hal itu menjadikan orang luar dengan mudah masuk ke dalam cluster. Saat ini pengamanan terhadap tamu hanya sebatas penitipan kartu identitas memungkinkan seseorang dengan asal menyebutkan nama salah satu penghuni. Pengawasan keamanan memang dilakukan selama 24 jam penuh di setiap kawasan cluster, namun dengan tidak dilakukannya pendataan tamu yang berkunjung secara terinci. Hal ini dirasa kurang dalam membantu proses keamanan.

Berdasarkan permasalahan yang ada, maka diusulkan untuk merancang sistem informasi data kependudukan pada cluster PT. Alam Sutera Realty Tbk. Aplikasi ini diharapkan dapat mempermudah Adm. Estate dalam mendata semua penduduk yang tersebar di beberapa cluster berikut laporan iuran dan dapat mempermudah petugas keamanan di setiap cluster untuk mendata tamu yang berkunjung.

Sistem informasi ini dirancang dengan menggunakan Data Flow Diagram sebagai model prosess dan Entity Relationship Diagam sebagai model basis datanya. Perancangan sistem informasi ini menggunakan bahasa pemrograman Visual Basic 6.0, basis data yang digunakan adalah Pemrograman Microsoft Access 2007, dan sistem operasinya dengan menggunakan Microsoft Windows XP.

Tujuan dari perancangan sistem informasi ini adalah untuk menghasilkan daftar cluster, daftar rumah, daftar pemilik, daftar penghuni, laporan RT, daftar keluar masuk penghuni, laporan tamu, rekap pembayaran, dan kartu untuk adm. estate, pengelola cluster, pemilik, penghuni, dan tamu guna sebagai cermin dari perkembangan dari PT. Alam Sutera Realty Tbk dan dapat memberikan informasi kepada tamu yang ingin berkunjung tetapi tidak tahu alamat penghuni. Rancangan ini cukup untuk kebutuhan divisi estate karena mengingat baru diterapkannya sistem komputerisasi pada pengelola cluster. 


\section{TINJAUAN PUSTAKA}

\section{A. Sistem, Informasi, Sistem Informasi, dan Sistem Informasi Manajemen}

Sistem adalah suatu kesatuan yang terdiri dari dua atau lebih komponen atau subsistem yang berinteraksi untuk mencapai tujuan tertentu [1].

Informasi didefinisikan sebagai hasil dari pengolahan data dalam suatu bentuk yang lebih berguna dan lebih berarti bagi penerimanya yang menggambarkan suatu kejadian-kejadian yang nyata yang digunakan untuk pengambilan keputusan [1].

Sistem informasi merupakan suatu sistem di dalam suatu organisasi yang merupakan kombinasi dari orang-orang, fasilitas, teknologi, media, prosedur-prosedur dan pengendalian yang ditujukan untuk mendapatkan jalur komunikasi penting, memproses tipe transaksi rutin tertentu, memberi sinyal kepada manajemen dan yang lainnya terhadap kejadian-kejadian internal dan eksternal yang penting dan menyediakan suatu dasar informasi untuk pengambilan keputusan yang cerdik [1].
Sistem informasi manajemen didefinisikan sebagai kumpulan dari interaksi sistem-sistem informasi yang bertanggung jawab mengumpulkan dan mengolah data untuk menyediakan informasi yang berguna untuk semua tingkatan manajemen di dalam kegiatan perencanaan dan pengendalian [1].

\section{B. Sistem Data Kependudukan pada Cluster}

Berdasarkan konsep arsitektur, cluster merupakan penataan beberapa rumah yang dikelompokkan ke dalam ruang bersama untuk mendapatkan kepadatan yang tinggi pada suatu area, sehingga lahan lainnya dapat dimanfaatkan untuk ruang terbuka [2].

\section{ANALISA DAN PERANCANGAN Sistem}

\section{A. Analisa Sistem Informasi}

Analisa pada sistem yang berjalan menggunakan dokument flowchart. Dokumen flowchart digunakan untuk menjelaskan sistem perusahaan yang sedang berjalan.

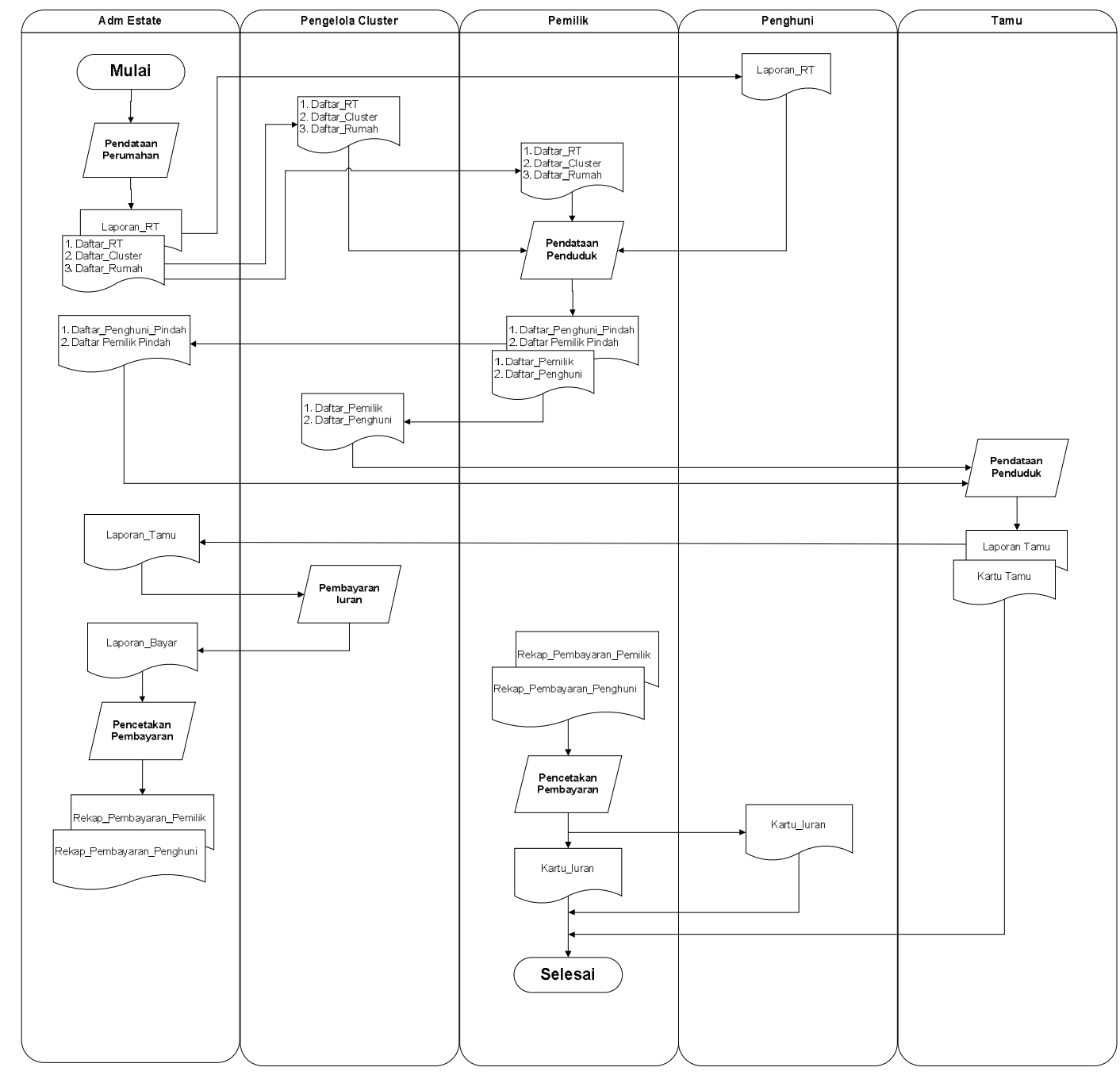


Gambar 1. Dokumen Flowchart Sistem Berjalan pada Cluster PT. Alam Sutera Realty Tbk.

Adm. Estate pada PT. Alam Sutera Realty Tbk melakukan pendataan perumahan yang kemudian menghasilkan Laporan_RT yang diberikan kepada Penghuni dan Daftar_RT, Daftar_Cluster, serta Daftar_Rumah diberikan kepada Pengelola Cluster dan Pemilik. Keempat laporan itu diproses untuk pendataan penduduk yang kemudian menghasilkan Daftar_Pemilik dan Daftar_Penghuni diberikan kepada Pengelola Cluster dan Daftar_Pemilik_Pindah dan Daftar_Penghuni_Pindah diberikan kepada Adm. Estate. Keempat keluaran tersebut diproses untuk pendataan kunjungan. Dari proses tersebut dihasilkan Laporan_Tamu dan Kartu_Tamu yangdiberikan masing-masing kepada Adm. Estate dan Tamu. Di dalam Adm. Estate, Laporan_Tamu diproses untuk pembayaran iuran yang kemudian menghasilkan Laporan_Bayar. Lalu diproses kembali dalam pencetakan pembayaran yang menghasilkan Rekap_Pembayaran_Pemilik, Rekap_Pembayaran_Penghuni, dan Kartu_Iuran.

\section{B. Perancangan Sistem Informasi}

\section{1) Bagan Berjenjang}

Bagan berjenjang berinteraksi antara menu-menu untuk membuka form-form yang telah dibuat, dirancang dengan konsep penggolongan dan hirarki. Bagan berjenjang didesain sedemikian rupa untuk memudahkan pemakai.

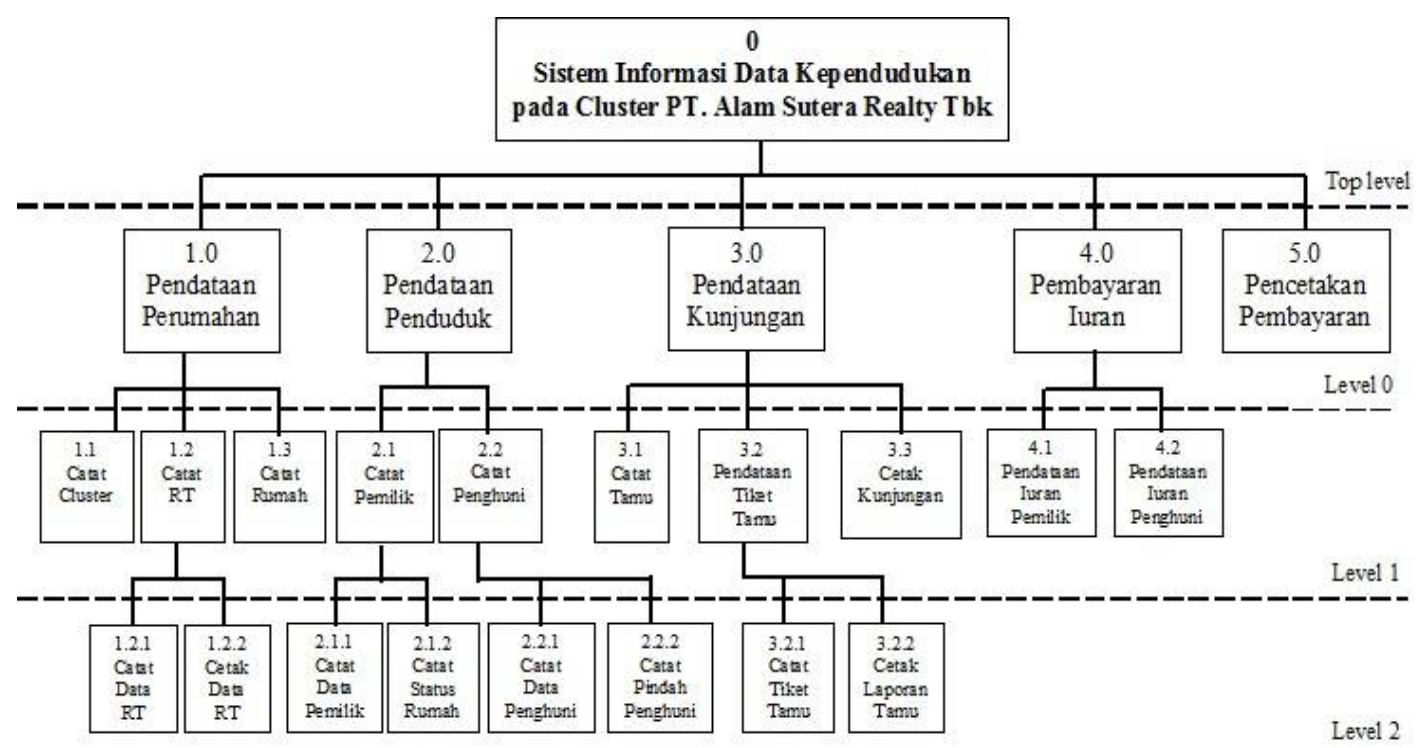

Gambar 2. Bagan Berjenjang Sistem Usulan Sistem Informasi Data Kependudukan pada Cluster PT. Alam Sutera Realty Tbk.

\section{2) Konteks Diagram ( Top Level)}

Konteks diagram merupakan awal masukan dan keluaran pada sistem informasi data kependudukan pada cluster PT. Alam Sutera Realty Tbk. Konteks diagram ini berfungsi menjelaskan alur berjalannya sistem data kependudukan pada setiap cluster di perumahan ini. Entitas yang terlibat antara lain : Pemilik, Penghuni, Pengelola Cluster, Adm Estate, dan Tamu. 


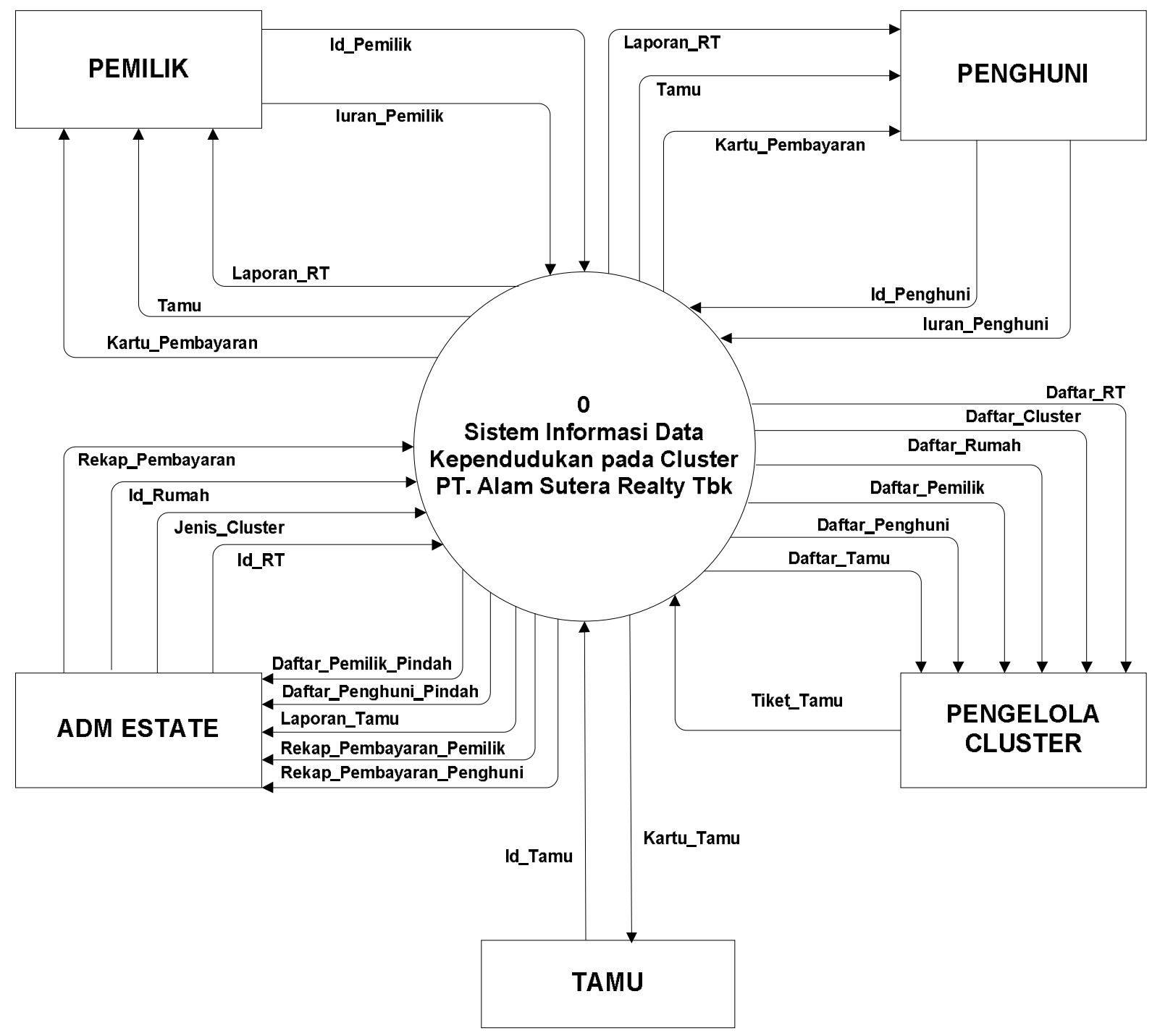

Gambar 3. Konteks Diagram Sistem Usulan Sistem Informasi Data Kependudukan pada Cluster PT. Alam Sutera Realty Tbk.

a) Pemilik memberikan input Id_Pemilik dan Iuran_Pemilik dan menerima Laporan_RT, Tamu, dan Kartu_Pembayaran.

b) Penghuni memberikan input Id_Penghuni, dan Iuran_Penghuni dan menerima Laporan_RT, Tamu, dan Kartu_Pembayaran.

c) Pengelola Cluster memberikan input Tiket_Tamu dan menerima Daftar_RT, Daftar_Cluster, Daftar_Stok_Rumah, Daftar_Pemilik, Daftar_Penghuni, dan Daftar_Tamu. d) Adm Estate memberikan input Id_RT, Jenis_Cluster Id_Rumah, dan Rekap_Pembayaran dan menerima Daftar_Pemilik_Pindah, Daftar_Penghuni_Pindah, Laporan_Tamu, Rekap_Pembayaran_Pemilik, dan Rekap_Pembayaran_Penghuni.

3) Diagram Overview (Level 0)

Diagram overview ini menjelaskan sistem pendataan perumahan, pendataan penduduk, pendataan kunjungan, pembayaran iuran, dan pencetakan pembayaran. 


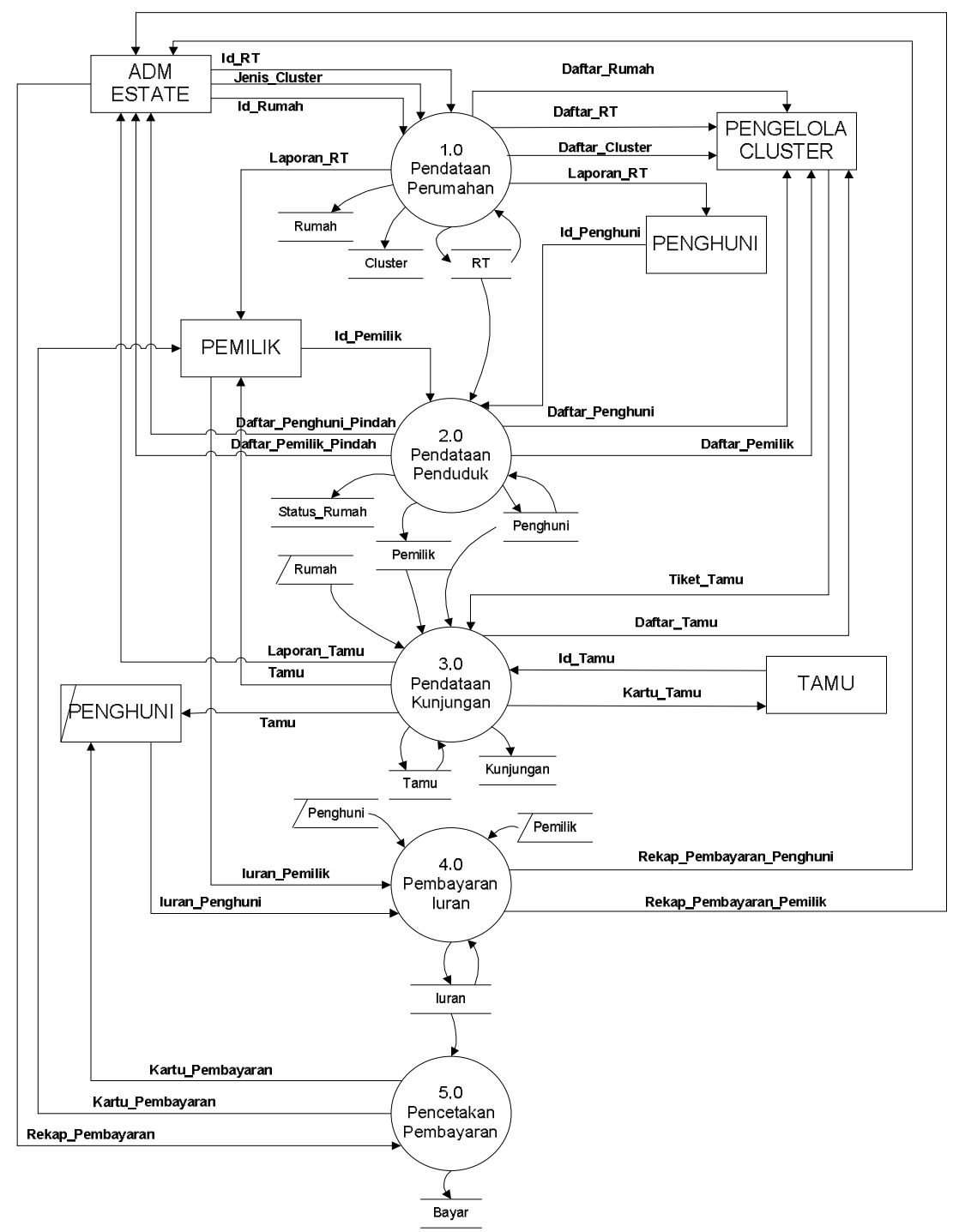

Gambar 4. Diagram Overview Sistem Usulan Sistem Informasi Data Kependudukan pada Cluster PT. Alam Sutera Realty Tbk

a) Proses 1 (Pendataan Perumahan)

Proses ini dimulai dari Adm Estate yang memberikan input Id_RT, dicetak Daftar_RT ke Pengelola Cluster dan disimpan pada data store RT, kemudian dibaca kembali data store RT lalu dicetak Laporan_RT ke Pemilik dan ke Penghuni, dan disimpan kembali pada data store RT. Adm Estate memberikan input Jenis_Cluster, dicetak Daftar_Cluster ke Pengelola Cluter, dan disimpan pada data store Cluster. Adm estate juga memberikan input Id_Rumah, dicetak

Daftar_Stok_Rumah ke Pengelola Cluster, dan disimpan pada data store Rumah.

b) Proses 2 (Pendataan Penduduk)
Proses ini dimulai dari Pemilik yang memberikan input Id_Pemilik dan Penghuni memberikan input . Id_Penghuni, dibaca data store RT, dicetak Daftar_Pemilik_Pindah ke Adm Estate dan Daftar_Penghuni ke Pengelola Cluster, dan disimpan pada data store Pemilik dan data store Penghuni. Pemilik kembali memberikan input Id_Pemilik, dicetak Daftar_Pemilik ke Pengelola Cluster, dan disimpan pada data store Status_Rumah. Penghuni kembali memberikan input Id_Penghuni, dibaca data store Penghuni, dicetak Daftar_Penghuni_Pindah ke Adm Estate, dan disimpan kembali pada data store Penghuni.

c) Proses 3 (Pendataan Kunjungan)

Proses ini dimulai dari Tamu yang memberikan input Id_Tamu, dibaca data store Pemilik, data store 
Penghuni, dan data store Rumah, dicetak Daftar_Tamu ke Pengelola Cluster, dan disimpan pada data store Tamu. Pengelola Cluster memberikan input Tiket_Tamu, dibaca data store Tamu, dicetak Kartu_Tamu ke Tamu dan Laporan_Tamu ke Adm_Estate, kemudian disimpan kembali pada data store Tamu. Tamu yang sudah memberikan input Id_Tamu, dicetak Tamu ke Pemilik dan ke Penghuni, disimpan pada data store Kunjungan.

d) Proses 4 (Pembayaran Iuran)

Proses ini dimulai dari Pemilik yang memberikan input Iuran_Pemilik, dibaca data store Pemilik, dicetak Rekap_Pembayaran_Pemilik ke Adm Estate, dan disimpan pada data store Iuran. Penghuni yang memberikan input Iuran_Penghuni, dibaca data store Penghuni, dicetak
Rekap_Pembayaran_Penghuni ke Adm Estate, dan disimpan kembali pada data store Iuran.

e) Proses 5 (Pencetakan Pembayaran)

Proses ini dimulai dari Adm Estate yang memberikan input Rekap_Pembayaran, dibaca data store Iuran, dicetak Kartu_Pembayaran ke Pemilik dan ke Penghuni, dan disimpan pada data store Bayar.

\section{4) Diagram Rinci}

Dalam diagram overview diatas masih ada beberapa proses yang perlu dirinci sehingga proses yang lebih sulit lebih dimengerti . Berdasarkan diagram overview terdapat 4 (empat) proses yang perlu dirinci, yaitu proses 1, proses 2 , proses 3, dan proses 4 . Berikut penjelasan dari masingmasing program sebagai berikut :

a) Diagram Rinci Level 1

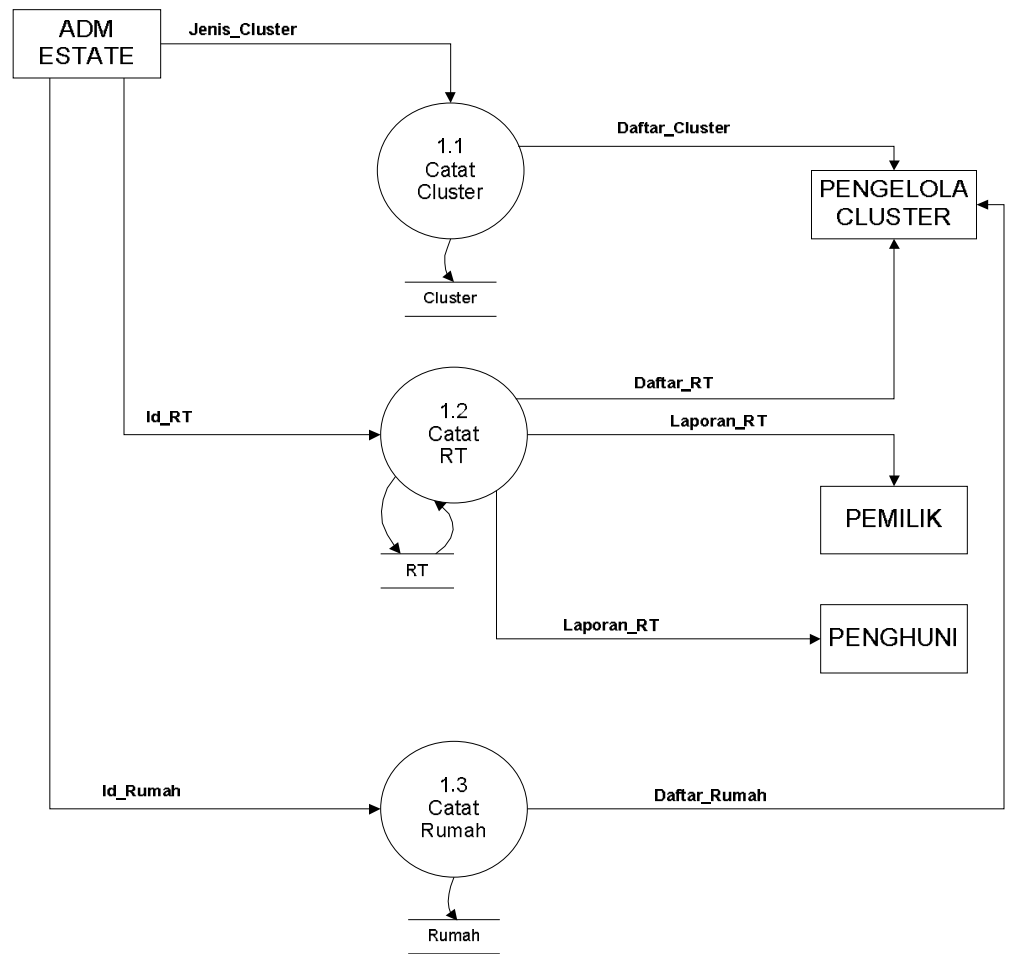

Gambar 5. Diagram Rinci Level 1 (Proses 1) Pendataan Perumahan

- $\quad$ Proses 1.1 (Catat Cluster)

Pada catat cluster ini, Adm Estate memberikan input Jenis_Cluster, dicetak Daftar_Cluster ke Pengelola Cluster, dan disimpan pada data store Cluster.

- $\quad$ Proses 1.2 (Catat RT)

Pada catat RT ini, Adm Estate memberikan input Id_RT, dicetak Daftar_RT ke Pengelola Cluster,
Laporan_RT ke Pemilik dan ke Penghuni, kemudian disimpan baca pada data store RT.

- Proses 1.3 (Catat Rumah)

Pada catat rumah ini, Adm Estate memberikan input Id_Rumah, dicetak Daftar_Stok_Rumah ke Pengelola Cluster, kemudian disimpan pada data store Rumah 
b) Diagram Rinci Level 1 (Proses 2)

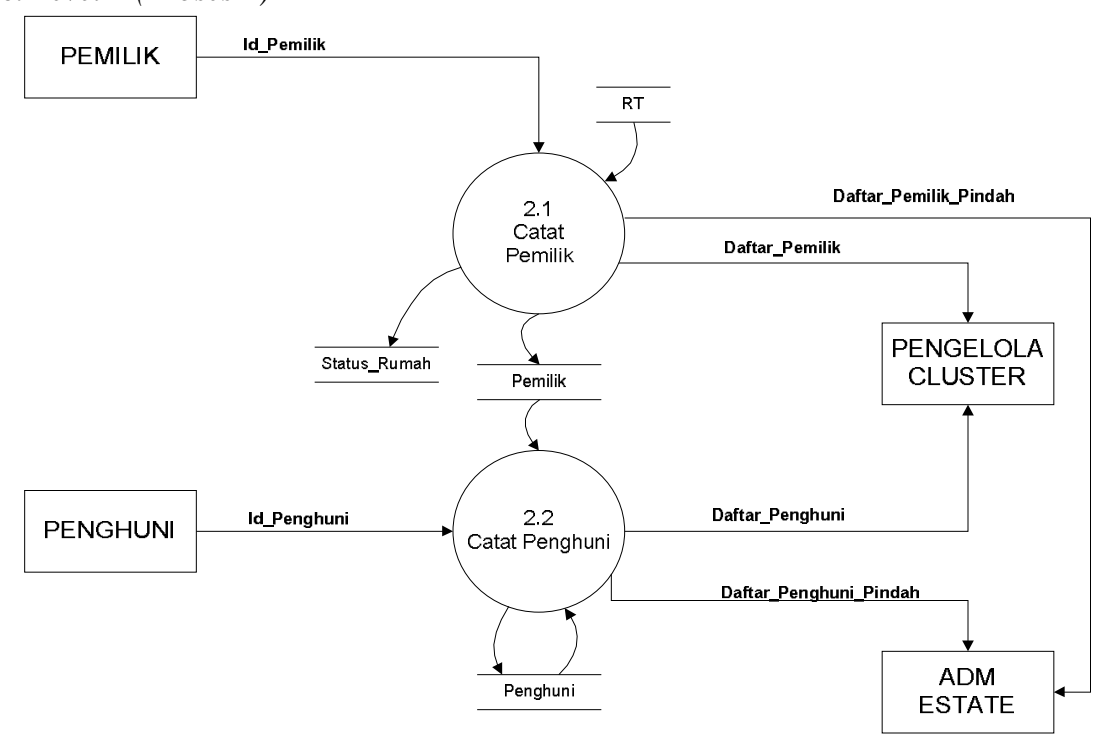

Gambar 6. Rinci Level 1 (Proses 2) Pendataan Penduduk

- $\quad$ Proses 2.1 (Catat Pemilik)

Pada catat data pemilik ini, Pemilik memberikan input Id_Pemilik, dibaca data store RT, dicetak Daftar_Pemilik_Pindah ke Adm Estate, dan disimpan pada data store Pemilik. Dicetak Daftar_Pemilik ke Pengelola Cluster, dan disimpan pada data store Status_Rumah.
- $\quad$ Proses 2.2 (Catat Penghuni)

Pada catat data penghuni ini, Penghuni memberikan input Id_Penghuni, dibaca data store Pemilik, dicetak Daftar_Penghuni ke Pengelola Cluster, dan disimpan pada data store Penghuni. Dibaca kembali data store Penghuni, dicetak Daftar_Penghuni_Pindah ke Adm Estate, dan disimpan kembali pada data store Penghuni..

c) Diagram Rinci Level 1 (Proses 3)

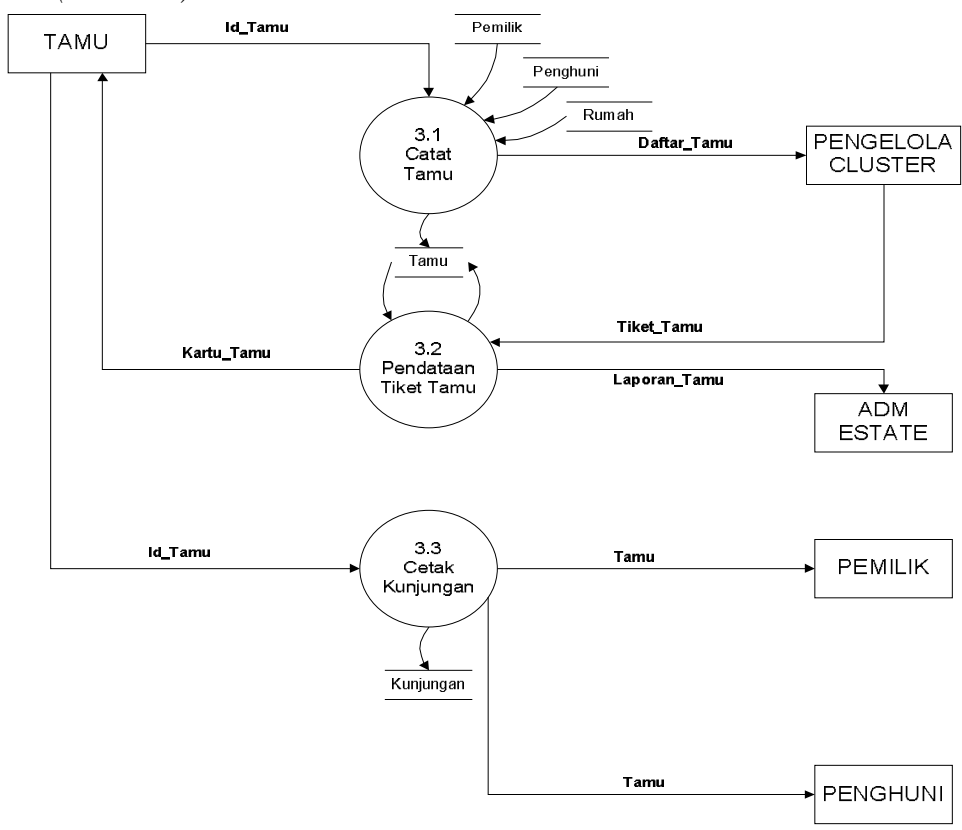

Gambar 7. Diagram Rinci Level 1 (Proses 3) Pendataan Kunjungan 
- Proses 3.1 (Catat Tamu)

Pada catat tamu ini, Tamu memberikan input Id_Tamu, dibaca data store Rumah, data store Pemilik dan data store Penghuni, dicetak Daftar_Tamu ke Pengelola Cluster, dan disimpan pada data store Tamu.
- $\quad$ Proses 3.2 (Pendataan Tiket Tamu)

Pada pendataan tiket tamu ini, Pengelola Cluster memberikan input Tiket_Tamu, dibaca data store

Tamu, dicetak Kartu_Tamu ke Tamu dan Laporan_Tamu ke Adm Estate, dan disimpan kembali pada data store Tamu.

- Proses 3.3 (Cetak Kunjungan)

Pada cetak kunjungan ini, tamu memberikan input Id_Tamu, dicetak Tamu ke Pemilik dan ke Penghuni, kemudian disimpan pada data store Kunjungan.

d) Diagram Rinci Level 1 (Proses 4)

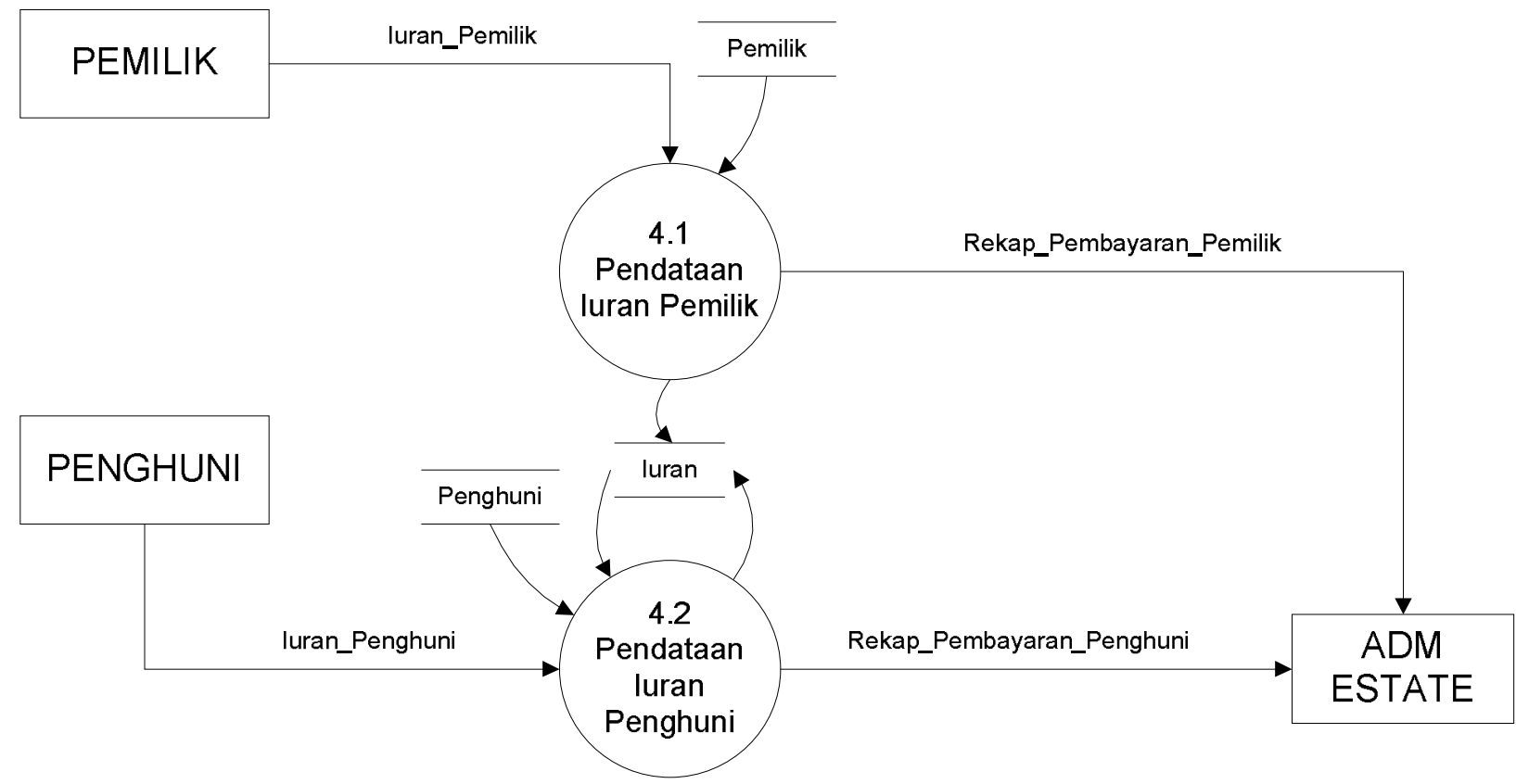

Gambar 8. Diagram Rinci Level 1 (Proses 4) Pembayaran Iuran

- $\quad$ Proses 4.1 (Pendataan Iuran Pemilik)

Pada pendataan iuran pemilik ini, Pemilik memberikan input Iuran_Pemilik, dibaca data store Pemilik, dicetak Rekap_Pembayaran_Pemilik ke Adm Estate, dan disimpan pada data store Iuran.
- $\quad$ Proses 4.2 (Pendataan Iuran Penghuni)

Pada pendataan iuran penghuni ini, Penghuni memberikan input Iuran_Penghuni, dibaca data store Penghuni, dicetak Rekap_Pembayaran_Penghuni ke Adm Estate, dan disimpan kembali pada data store Iuran.

\section{Analisa Basis Data}

Analisa Basis Data (database) yang dibuat untuk menyimpan data-data pada divisi estate PT. Alam Sutera Realty Tbk. Isi dari database ini adalah tabel-tabel untuk keperluan Adm Estate serta untuk keperluan aplikasi yang dibuat untuk Pengelola Cluster dalam PT. Alam Sutera Realty, Tbk. Adapun untuk mendapatkan rancangan basis data yang efektif diperlukan pendekatan sebagai berikut :

1) Entity Relation Diagram (ERD)

Entity Relation Diagram (ERD) menyatakan bagaimana tabel-tabel berhubungan satu sama lain. 


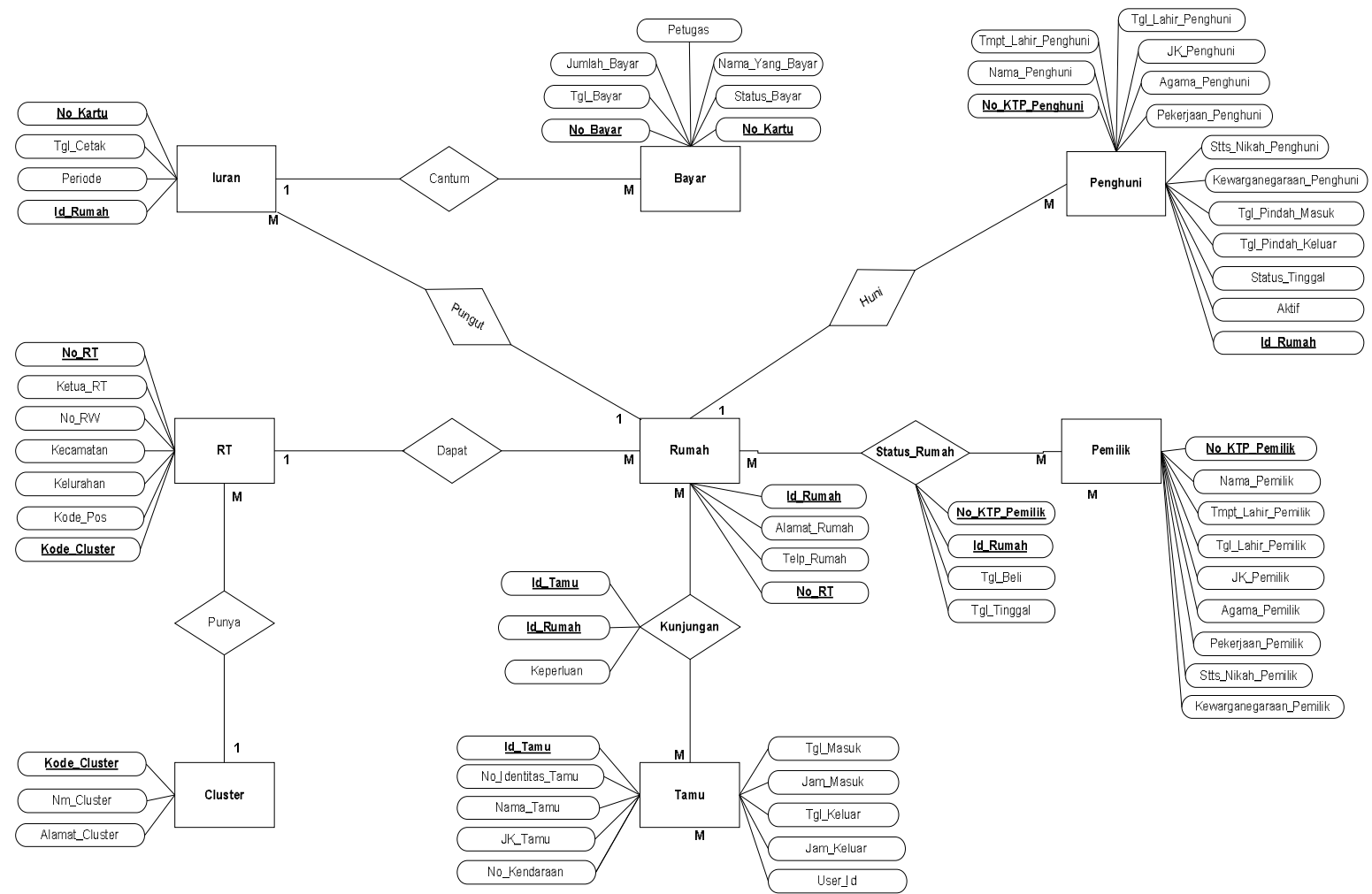

Gambar 9. Entity Record Structure (ERD) Sistem Usulan Sistem Informasi Data Kependudukan

\section{2) Logical Record Structure (LRS)}

Logical Record Structure (LRS) merupakan gambaran hubungan antar record atau tabel yang berbentuk kotak persegi panjang dengan nama yang unik. LRS menyatakan bagaimana tabel-tabel yang dihasilkan dari rancangan proses yang berhubungan satu dengan yang lain.

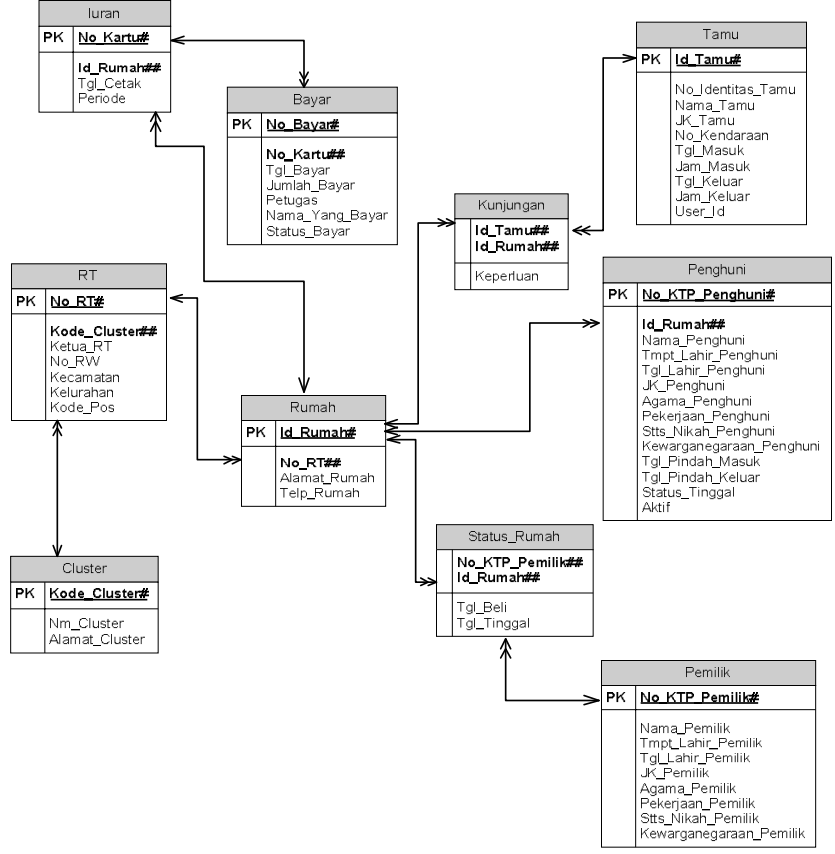

Gambar 10. Logical Record Structure (LRS) Sistem Usulan Sistem Informasi Data Kependudukan 


\section{PENUTUP}

\section{A. Kesimpulan}

Berdasarkan hasil perancangan sistem informasi data kependudukan pada PT. Alam Sutera Realty Tbk, dapat disimpulkan hal-hal sebagai berikut:

- Dapat menghasilkan data kependudukan yang diperlukan seorang adm estate, pengelola cluster, pemilik, penghuni, dan tamu.

- Menghasilkan data yang lebih akurat dan tepat waktu oleh divisi estate dalam pengambilan keputusan.

- Memberikan kemudahan dalam proses penginputan dan pengontrolan data kependudukan.

- Dapat memberikan informasi kepada tamu yang ingin berkunjung tetapi tidak mengetahui alamat atau nama penduduk.

- Menghasilkan daftar cluster, daftar rumah, daftar pemilik, daftar penghuni, laporan RT, daftar keluar masuk penghuni, laporan tamu, rekap pembayaran, dan kartu untuk adm. estate, pengelola cluster, pemilik, penghuni, dan tamu..

\section{DAFTAR PUSTAKA}

[1] Hartono Jogiyanto, (2005), Analisis \& Desain Sistem Informasi Pendekatan Terstruktur Teori dan Praktek Bisnis, Yogyakarta:Andi.

[2] H.M Jogiyanto, [2005], Pengenalan Komputer Dasar Ilmu Komputer, Pemrograman, Sistem Informasi dan Intelegensi Buatan, Jogyakarta:Andi.

[3] Connolly Thomas,(2002), Database systems : A Practical Approach to Design, Implemntation, and Management, Third Edition, England: Addition Wesley Publishing Company Inc.

[4] Mcleod, Raymond JR, Goerge Schell, Arthur I. Stonehill, \& Michael H. Moffet. 2004. Sistem Informasi Manajemen, Edisi Bahasa Indonesia. Jakarta : Indeks.

[5] Munir. 2010. Kurikulum Berbasis Teknologi, Informasi, dan Komunikasi. Bandung: Alfabeta. 